\title{
The (mis)interpretation of the Bible in South Africa: Towards a better hermeneutic
}

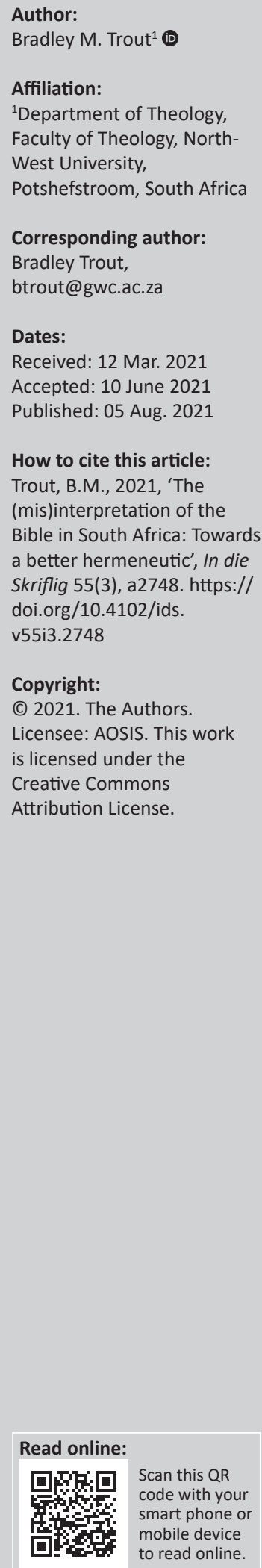

The Bible continues to have a prominent place in the South African discourse. Unfortunately, however, it is often poorly interpreted. The purpose of this study was to examine the nature of the misinterpretation of the Bible. We aimed to uncover the specific interpretive methods responsible for this misinterpretation, considered generally in the South African milieu. Specifically, we discussed the role of biblical fundamentalism. Essentially fundamentalism fails to account for the reader's place in the process of biblical interpretation and so operates under the guise of false objectivity. We then discussed three examples of this phenomenon: the way in which Scripture has been interpreted by the African Christian Democratic Party, Peter Hammond's view in his Biblical principles for Africa, and the scriptural interpretation of Deuteronomy by Dutch Reformed theologians in the 1930s-1960s. This essay demonstrated that the primary problem with the fundamentalistic method is its failure to account for the reader's role in the interpretive process. Fundamentalism presents itself in several ways as 'biblical' without recognising the problems inherent in such a formulation, especially in the assumption of objectivity. This result illustrated the necessity for a more reader-centred approach to Scripture that takes note of prior ideological commitments. As a result, it is imperative that we embrace a hermeneutic that is firstly 'critical', that means willing to interrogate ideological pre-commitments. Secondly, we proposed that the hermeneutic focus on 'eschatology', whereby Scripture is considered primarily based on its redemptive trajectory. The emphasis is then placed on the Christ event, especially the resurrection as the culmination of the story. Biblical ethics are then grounded in an understanding of the people of God as the eschatological community. This approach is also termed 'redemptive-historical'. As one example of such an approach, we discussed N.T. Wright's Five-act model. In this view, biblical ethics are grounded upon knowing where we find ourselves in the overall drama and what is appropriate within each act. God's people are to imagine themselves as players in a later stage of the same grand drama of Scripture. This hermeneutic provides, so we argued, a better approach to applying Scripture in the modern context. If we wish to reduce the misinterpretation of Scripture in the South African milieu, we need to identify fundamentalist hermeneutics and continually strive towards a more readercentred and eschatological approach to its interpretation.

Contribution: This article attempted to contribute towards our understanding of the way Scripture is used in public discourse, and it also suggested a way forward to a better interpretation.

Keywords: interpretation; Fundamentalism; hermeneutics; Bible; reader; eschatology; South Africa.

\section{Introduction}

That the Bible continues to play an important role in South African discourses may be seen on several levels. Recently Chief Justice Mogoeng Mogoeng prayed (News24 2020:1):

I lock out any vaccine that is not from you ... if there be any vaccine that is of the devil, meant to infuse triple-six in the lives of people, meant to corrupt their DNA, any such vaccine, Lord God Almighty, may it be destroyed by fire, in the name of Jesus.

Leaving aside the concerning attitude towards vaccines here exhibited by the Chief Justice, I want to pick up on the reference to 'triple-six' and its 'infusion' in people's lives. The idea of 666 is drawn from Revelation 13:15-18:

The second beast was given power to give breath to the image of the first beast, so that the image could speak and cause all who refused to worship the image to be killed. It also forced all people, great and 
small, rich and poor, free and slave, to receive a mark on their right hands or on their foreheads, so that they could not buy or sell unless they had the mark, which is the name of the beast or the number of its name This calls for wisdom. Let the person who has insight calculate the number of the beast, for it is the number of a man. That number is 666 .

It is hardly necessary to point out that this verse, written late in the first century (or even in the second century), could not be referring to vaccines in the 21st century. Such a method of reading Revelation is known as 'futurism'. Futurism sees the events described in the book of Revelation as pointing toward some future period when these things will take place in some literal manner. Futuristic readings of Revelation (and Daniel) have been popularised in Africa through a theological system called dispensationalism, which is a recent trend in the history of the church. Our purpose here is not to discuss futurism, dispensationalism and the mark of the beast - plenty has been written on these subjects and it is widely available. Rather, I aim to show that such interpretations of the Bible continue to play an important role in the mainline South African discourse.

In the first part of this article, I want to take a closer look at one way the Bible is interpreted in South Africa. Especially we need to understand fundamentalism and the way it has played out in the political sphere, not least in the African Christian Democratic Party (ACDP). In the second part of the article, we will discuss a better approach to Scripture.

\section{Fundamentalism in South Africa}

Chief Justice Mogoeng's use of triple-six language comes straight from the interpretive method of biblical fundamentalism. Fundamentalism has been discussed in several works over the years and is described in multiple ways.

One major work on the subject is James Barr's Fundamentalism (1981). Barr begins by noting the inadequacy of 'the plain man's definition', which is that a fundamentalist 'is a person who takes the Bible literally'. Barr (1981) lists three 'pronounced characteristics':

- A very strong emphasis on the inerrancy of the Bible, the absence from it of any sort of error;

- A strong hostility to modern theology and to the methods, results and implications of modern critical study of the Bible;

- An assurance that those who do not share their religious viewpoint are not really 'true Christians' at all. (p. 1)

A recent book discussing the nature of fundamentalism, cites the work of Egginton ${ }^{1}$ and places the locus of the concept more on how someone believes, than on what someone believes. Pickering (2019) describes it clearly:

1.Eggington once posted his description of What is fundamentalism? in Arcade: Literature, the Humanities \& the World, in https://arcade.stanford.edu/blogs/whatfundamentalism and Pickering consults it in his description in 2019
While Christians from several traditions would agree that the text of the Bible is the source of the content of our faith, to be fundamentalist implies that one holds to this content with a certain attitude. 'A fundamentalist', continues Egginton, 'implicitly holds that what he believes corresponds to a single, underlying code that explains everything about the world, in its totality'. The manner in which this is lived out tends to set fundamentalists at odds with society and those who disagree with their outlook ... To accuse people of being fundamentalist, therefore, is not merely a statement about their belief in, for example, the inspiration of Scripture or its inerrancy. It implies that they exhibit a mindset towards the Bible and its application that makes them rigid and intolerant of those who differ from them. It is to accuse them of being over-confident in their own correctness, lacking in nuance, and blind to the effects of their own human weakness and corruption on their thinking. (p. 14)

Whereas Barr discusses the 'pronounced characteristics' of fundamentalism, Pickering focuses on the fundamentalist's 'mindset'. The former examines the fundamentalist hermeneutic while the latter examines its posture. Both describe important aspects of fundamentalism, but it is the former - Barr's characterising - which I hope to build upon, as that remains relevant in present-day South Africa.

We need to pay attention especially to Barr's (1981:1) second 'pronounced characteristic': 'a strong hostility to modern theology and to the methods, results and implications of modern critical study of the Bible'. Fundamentalism tends to reject the results of modern scholarship. Examples could include the mythological nature of the creation accounts, or the authorship of the Torah. In each instance, the fundamentalist position fails to accept the consensus of modern scholarship (see Enns 2015:13-59).

But in this article, I want to build on a further aspect of fundamentalism not mentioned specifically by Barr or Pickering. Barr spoke specifically about fundamentalist aversion to 'modern theology and methods'. The same should be said for its aversion to postmodern theology and its methods. While space unfortunately prohibits a fuller discussion here, I would argue that a basic understanding of fundamentalism, hermeneutically speaking, is that it fails to account for the reader's place in the process of biblical interpretation and so operates under the guise of false objectivity (cf. Smith 2012). Political and economic ends are declared 'biblical', with no questions asked on the interpreter's presuppositions or ideological commitments. This is the fundamental quality of fundamentalism.

I will seek to illustrate this point by providing some examples of fundamentalism in the South African context. The first is provided by the Chief Justice as quoted above. But it would also be worthwhile to consider the hermeneutical approach of the ACDP, led by the Reverend Kenneth Meshoe. We also consider a typical example in Peter Hammond's Biblical 
principles for Africa. Finally, we consider the interpretation of Deuteronomy during the early Apartheid years.

\section{The African Christian Democratic Party}

The ACDP present themselves in South African politics as the party that 'is built on a strong biblical foundation, that seeks to honour God and put you and your needs at the center of its policies'. It is beyond the scope of this article to provide a thorough analysis and critique on the ACDP. Our purpose is merely to cite them as illustrative of the phenomenon of fundamentalism in South Africa.

The problem is essentially hermeneutical in nature. While the ACDP claims to be built on a 'biblical foundation', the key question is: what does this biblical foundation look like in practice? It is interesting to observe the Scripture references intended to support ACDP policies (ACDP 2020):

- On the reinstating of the death penalty: "The ACDP strongly supports the introduction of capital punishment for certain violent crimes (Nm 35:30-33, Gn 9:6, Ex 20:3, Lv 24:17-22, Mt 5:17, Rm 13 and Rev 13:10)'.

- On the family: 'The family is an institution worthy of nurturing and protecting. It is the ideal setting for teaching a child about Godly authority, obedience and love which are the foundations for a strong nation (Dt 6:6-9)'. 'The problems in South Africa', according to the ACDP manifesto (ACDP 2019), result from the apartheid institutionalised separation of families. As a result of broken families 'delinquency, crime and violence usually occur'.

- The ACDP's commitment: 'We, the ACDP, acknowledge God as the Sovereign Creator of the universe, who has entrusted unto humanity the right and responsibility to rule over the affairs of the world ... The ACDP commits itself to this nation to uphold a leadership of integrity and Godly character, and to administer its task with a prudent spirit ... We adhere to a moral philosophy that is based upon the Word of God, and measure the interpretation of our policies against the prerequisites of biblical standards'.

- On education: 'Education must be pro-active in moral and redemptive teaching. It must teach respect for the dignity, as well as the fallibility of human nature and provide an understanding of the centrality of God'.

At issue here is not any specific policy. What is of interest for the purpose of this contribution, is the way in which Scripture is employed - their hermeneutics. I want to make three related observations in this regard.

Firstly, they represent merely one take on 'biblical foundations'. Other Christians equally committed to 'biblical foundations' arrive at different conclusions on the same matters. How is it that separate groups of Christians with the same 'biblical foundation' come to completely opposite conclusions on, say the death penalty? The ACDP claims to apply biblical authority, but it is their interpretation of biblical authority that they are applying. One must distinguish between the issues of authority and interpretation.

Secondly, their conclusions are arrived at by following no declared strategy of biblical interpretation. The problem of hermeneutics is well-known, as no one simply 'does' what the Scripture teaches. Such a straightforward reading strategy - attempted at times with humorous results (see Jacobs 2007) - is in fact untenable. On what basis then, do organisations such as the ACDP decide which portions of Scripture apply directly to South African voters in the 21st century? And which portions are limited to the original context? A tremendous amount of scholarship has gone into questions like this, but it is difficult to see any reflection of them in the manifesto of the ACDP (2019).

Thirdly, when it comes to the texts they do cite, there is no discussion of the historical and literary context of the passages, or the culture into which those texts were written. No attention is given to the stage of redemptive history in which the texts took place. They are simply assumed to be relevant. This rejects modern historical-critical and literary biblical research, in line with Barr's description of fundamentalism. Furthermore, they fail to recognise that the simple quotation of texts supports a specific political ideology and cannot in any meaningful sense be presented as 'biblical'. It is therefore a fundamentalist approach to Scripture.

\section{Biblical principles for Africa}

A second example of fundamentalism in South Africa is provided by Peter Hammond. Hammond is the founder and director of Frontline Fellowship, Christian Action, and the Reformation Society. He has written many books, but for our purposes we will focus on Biblical principles for Africa.

What then are the 'biblical principles' that should be applied in Africa? The opening page of the book (see Figure 1) represents the same problem we attempted to describe above: a failure to acknowledge ideological pre-commitments.

Of interest is the simplicity of the dichotomy: 'the Word of God' or 'the philosophy of man', the failure to acknowledge that the Word of God is always interpreted through 'the philosophy of man', which goes either unknown or unacknowledged. The same could be said of concepts like 'the Bible' when juxtaposed against 'philosophy', and so on, as we work our way down the list. The rest of the book discusses matters such as the following:

- 'The biblical solution to crime' - which seems to pay much more attention to the justice system of the Old Testament than to the Sermon on the Mount (cf. Gushee 2016, who gives the Sermon on the Mount hermeneutical priority):

- 'Free enterprise and honest money' - which is merely a biblical defence of capitalism.

- 'Biblical principles of government' - which resembles the theological system of theonomy. 


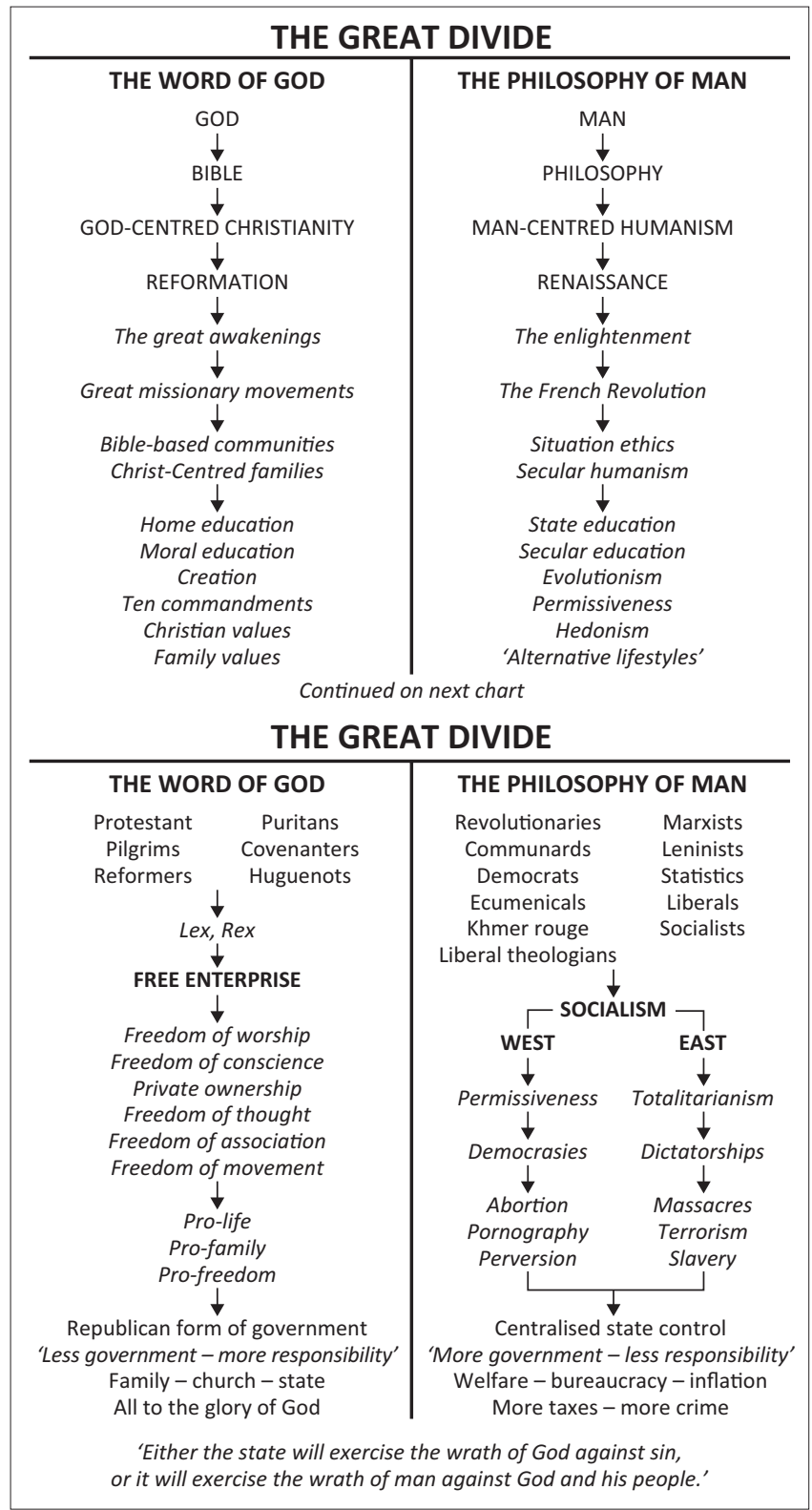

Source: Hammond, P., 2008, Biblical principles for Africa, p. ix, Christian Liberty Books, Cape Town

FIGURE 1: Hammond's 'Great Divide' between God's Word and Man's philosophy on the opening page of Biblical Principles for Africa.

- 'Biblical commands to a nation' - which makes little distinction between the nation of Israel in the Old Testament and the modern-day church, eschewing the discussion of the 10 Commandments and their modern application.

- 'Poverty: its cause and cure' - which places emphasis on the individual rather than systemic injustice.

- 'God's law or chaos' - which fails to adequately delve into the tricky discussion of applying 'God's law' in the modern world.

In these chapters Hammond's use of Scripture is problematic for similar reasons cited above when discussing the ACDP. Verses are cited with little or no appreciation for their own historical and literary context. Furthermore, no strategy is made clear for bridging the gap between the Testaments and modern Christianity. It's one thing to call for obedience to 'God's law', but another to delineate precisely how this should be done. For instance, Hammond is not calling for his readers to eat only kosher foods (despite Dt 14), neither is he calling for the worship of God on Saturday (despite the fourth commandment). Clearly there is some method for determining what obedience to God's law looks like in practice, but it is never specified. Because of this, verses and concepts are used to prop up a certain theological vision (something akin to theonomy). This is another example of fundamentalism.

This is not meant to be a thorough critique of Biblical principles for Africa, but men like Hammond have had widespread influence on Christianity in this country through ministries like Frontline Fellowship and in his capacity as a contributor to Joy Magazine. I cite Biblical principles for Africa as typical of a larger problem: undeclared or unacknowledged ideological commitments and how that forms his reading of Scripture. Hammond's book reads very much like those in the United States who wish to 'Make America Great Again'. It is unsurprising to find an endorsement of Biblical principles for Africa by the ACDP leader, reverend Meshoe, who calls it a 'Masterpiece'.

Once again, this is not the place for delving into these problematic dichotomies and the modernistic assumptions that underlie them (cf. Bartholomew 2000; Gadamer 1992; Westphal 2012). Derrida, as quoted in an interview by Kearney (2004), summarised the essential problem:

In all the other disciplines ... there is philosophy. To say to oneself that one is going to study something that is not philosophy is to deceive oneself. It is not difficult to show that in political economy, for example, there is a philosophical discourse in operation. And the same applies to mathematics and the other sciences. Philosophy, as logocentrism (see Vanhoozer 1998:53), is present in every scientific discipline, and the only justification for transforming philosophy into a specialized discipline is the necessity to render explicit and thematic the philosophical subtext in every discourse. The principle function which the teaching of philosophy serves is to enable people to become 'conscious', to become aware of what exactly they are saying, what kind of discourse they are engaged in when they do mathematics, physics, political economy, and so on. There is no system of teaching or transmitting knowledge which can retain its coherence without, at one moment or another, interrogating itself philosophically, that is, without acknowledging its subtextual premises, and this may even include an interrogation of unspoken political interests or traditional values. (p. 146)

Yet the assumption that it is possible to do theology without said 'subtextual premises', appears to be prevalent in much of popular Christianity.

\section{Misinterpretation of Deuteronomy}

One further example: The failure to recognise the problem described above, caused damage to the witness of the church in South Africa. In Ferdinand Deist's (1994) article, 'The dangers of Deuteronomy: A page from the reception history of the book', he sketched out the painful history of Deuteronomy's interpretation by the Dutch Reformed Church's theologians of the 1930s-1960s. The problem with 
these interpreters of Deuteronomy was precisely the problem we attempted to describe before: failure to interrogate their own ideological pre-commitments. Deist (1994) hoped that his research will stimulate increased self-awareness:

It is hoped that this tragic history will encourage biblical scholars to become critically aware of the profound influence exerted on the 'meaning' of a biblical passage by their hermeneutical presuppositions, epistemological choices, and their historicity as readers of texts. (p. 13)

After showing how theologians and ministers during this period abused the text of Deuteronomy, Deist (1994) ended his article with a warning about the importance of reader-centred hermeneutic approaches:

The country is presently paying a very high price for apartheid. Moreover, as a result of the consequences of the ecclesiastical Biblical interpretation of the past sixty years outlined above, the Dutch Reformed Church has lost its credibility for and the Bible its appeal to many Afrikaans speaking and black people. Apart from the loss of human dignity, this is perhaps our most costly spiritual loss. It will be an uphill battle to convince people that the Bible and the gospel of Jesus Christ have anything to contribute to their humanity and self-understanding. The whole exercise was an enormous disaster ... The South African experience points to the critical importance of a heavy emphasis on reader-oriented hermeneutical approaches and the creation of a critical consciousness of the historicity of any piece of literature and any form of interpretation, and therefore on the ethics of interpretation. (pp. 28-29)

Deist pointed to the importance, firstly of developing an emphasis on reader-orientated hermeneutical approaches. Second, he called for 'the creation of a critical consciousness of the historicity of any piece of literature'. This again located the fundamental problem in the failure of the fundamentalist to appreciate the process of interpretation both at the level of the reader and the level of the text. That texts need to be understood at that specific historical moment, is a key tenet in modern study of the Bible, overlooked by a fundamentalist interpretation which sought to utilise these texts towards their own ends.

\section{The essential problem}

In each of the examples above, the failure has been to adequately account for what readers bring to texts. Under the guise of false objectivity, the fundamentalist method frequently abuses Scripture and consequently discredits it in the eyes of the public, who assume that it is the only way it could be read.

While it is not the purpose of this article to delve into the hermeneutics that allowed pro-Apartheid readings of Scripture to flourish, it should be noted that statements about 'biblical foundations' require disclosure of the methods used in order to arrive at such an assessment of what is 'biblical'. Failure in this regard, enables powerful people to utilise Scripture to support the maintenance of their power. History - not least South African history - is replete with examples of the dangers encountered when people speak of being 'biblical', without declaring their method of ascertaining what constitutes 'biblical'.

A recent piece by Dion Forster in The conversation (2021) is titled, 'Trump is out, but US evangelicalism remains alive and well in Africa'. Forster (2021) discusses 'Trumpism' which he defines as:

... loosely [denoting] views on identity politics, nationalisms of various kinds and a series of reason-defying beliefs. Fuelled by secretive global organisations such as QAnon, there is also a strong dose of science denialism about climate change and COVID-19.

Forster (2021) further outlines some reasons why it flourishes in certain parts of Africa and discusses several reasons why some African evangelicals have adopted 'this brand of politically infused American Christianity so uncritically'. He lists several contributing factors, including how American evangelicalism resonates both with African spirituality and the materialism and individualism of modernity (see Balcomb 2016). Forster does not, however, discuss the hermeneutics bequeathed to us by American fundamentalism. Through their vast influence on this continent - not least through the efforts such as the missionaries of the Southern Baptist Convention - US evangelicalism has shared with us much of its naïve reading of Scripture, with the political, economic and social pre-commitments veiled behind a veneer of the so-called biblical.

The following section attempts to sketch out a better hermeneutic

\section{Towards a hermeneutic}

In his book, Moral vision of the New Testament, Richard Hays (1995) lays down the gauntlet:

Those who can naïvely affirm the bumper-sticker slogan, 'God said it, I believe it, that settles it', are oblivious to the questionbegging inherent in the formulation: there is no escape from the imperative of interpreting the Word. Bumper-sticker hermeneutics will not do. (p. 3)

I have tried to argue, up to this point, that what Hays calls 'bumper-sticker hermeneutics', is a hermeneutical approach operating in South Africa, as demonstrated by the likes of Justice Mogoeng's comments, the ACDP, and books such as Biblical principles for Africa. But one cannot merely criticise the fundamentalism so prevalent in biblical reception in South Africa. One must also attempt to forge a better hermeneutic.

I am aware that more sophisticated reading approaches to Scripture are readily available. As far back as 1986, The Kairos Document advocated a more just biblical reading strategy in the face of the fundamentalist use of Scripture from the Apartheid defenders. For example, The Kairos Document draws attention to a hermeneutic that acknowledges the context of the reader in biblical interpretation: 
Black theology, African theology and the theology of the African independent churches have already laid great emphasis upon the biblical teaching about suffering specially the suffering of Jesus Christ. When we read the Bible from the point of view of our daily experience of suffering and oppression, then what stands out for of us is the many, many vivid and concrete descriptions of suffering and oppression throughout the Bible culminating in the cross of Jesus Christ. (Kairos Document 4.2)

Furthermore, works such as Gerald West's Biblical hermeneutics of liberation (1991) argued that reader-centred hermeneutics are important for South Africans reading the Bible in the struggle for justice. The first chapter, for instance questions 'any mode of enquiry that tries to deny its own hermeneutic character and mask its own historicity so that it might claim ahistorical certainty' (West 1991:4), by making 'clear' 'the situatedness of both the text and the reader' (West 1991:29). This need for a robust hermeneutic that acknowledges the situatedness of the text and the reader, has been articulated for some decades. Yet, it remains necessary for this understanding to 'land' in the public sphere.

Therefore, how might a better public hermeneutic take shape? This article suggests a positive hermeneutic that is both critical and eschatological.

\section{A critical hermeneutic}

Above we have described the tendency of fundamentalism to proceed theologically with unacknowledged assumptions and pre-commitments. Moving forward, there remains a need for a critical examination of the assumptions economic, political, and theological - that readers bring to texts. By 'critical', I mean willing to interrogate ideological precommitments. I am referring specifically to the recognition of the impossibility of objectivity in interpretation, including the recognition that certain philosophical positions are always present in the interpretive process. This is a move that some conservative scholars have already incorporated into their hermeneutics texts. It is explained well by Osborne (2006):

Some have charged proponents of a reader-orientated criticism with undue scepticism, but the difficulties of objective interpretation are far too great for such a charge to be valid. The simple fact is that all of us read a text on the basis of our own background and proclivities. It is not only impossible but dangerous to put our knowledge and theological tradition aside as we study a biblical text. (p. 466)

\section{Vanhoozer (1998) also states:}

I concede that reading is never straightforward and that naïve understanding is never adequate. The kind of literary knowledge that emerges at the end of this study, therefore, will be one that is chastened, not absolute. (p. 25)

The call is for caution when approaching texts. The authors quoted above are conservative American scholars. Yet, it seems to me, as someone who has taught in several conservative theological institutions in South Africa, that there has been a reluctance to embrace a hermeneutic that acknowledges the context of the reader in conservative institutions. The reasons possibly relate to a perceived slide into pluralism. West (1991) anticipates this concern and cites the work of West and Tracy, saying, that they:

Both recognize the powerful negative hermeneutic potential of moving beyond objectivism. However ... both West and Tracy also argue for a positive hermeneutic which goes beyond scepticism and nihilism. Their positive hermeneutic consists of a prophetic vision of resistance and hope that roots their interpreting within an active and transformative solidarity with a particular community, the community of the poor and oppressed. (p. 29)

A 'chastened' hermeneutic is necessarily both critical (sceptical) and positive. It is critical of the assumptions and ideological pre-commitments readers bring to texts. Yet it also sees in the Christian Scriptures motifs, which ground interpretation in the biblical vision. Next, we discuss one such motif, namely eschatology.

\section{An eschatological hermeneutic}

Several books have attempted to address the hermeneutic problem in evangelicalism (cf. McKnight 2018; Osborne 2006; Smith 2012; Thiselton 1997; Vanhoozer 1998; Webb 2001; and others). Unfortunately, most of these writers are American or British and appear to have had minimal impact on popular (South African) evangelicalism, which is still characterised by proof-texting and unquestioned assumptions - as I tried to illustrate above.

Several authors have brought eschatology to the fore to articulate a viable hermeneutic. Space precludes a serious consideration of their contributions. Nonetheless, we can discuss the way in which a robust eschatology contributes to a chastened hermeneutic.

In his work, Inspiration and incarnation, Pete Enns describes a hermeneutic he terms 'christotelic', when reading the Old Testament. He prefers this term over 'christological' or 'christocentric' - terms that often tend to refer to seeing Christ in every Old Testament passage. Since telos refers to an 'end or completion', 'to read the Old Testament "christotelically" is to read it already knowing that Christ is somehow the end to which the Old Testament story is heading' (Enns 2015:247).

The final line above emphasises the idea of 'story' as central to the meaning of Scripture and pays attention to where the story is heading. Key to this approach is emphasising the eschatological trajectory of the biblical story. Scripture is considered primarily based on its redemptive trajectory and 'big picture' (Enns 2015:265). This interpretation lands up placing the emphasis on the Christ event, especially the resurrection, as the culmination of the story. Discipleship is then grounded in living as part of the story, as the eschatological community of the new creation. This approach 
could be termed 'redemptive-historical'. Below one such approach is discussed.

\section{Wright's 'Five-Act' model}

This hermeneutic has been best described by N.T. Wright in his magisterial New Testament and the people of God (1992:121-144), as well as in Scripture and the authority of God (2005:88-92). Wright (2005) begins by noting the problem we have tried to outline here:

We need, more especially, a multi-layered view of scripture, corresponding to that which we discerned among the earliest Christians. We must recognize the vital importance of genre, setting, literary style, and so on, and the all-important differences these things make to how we read the relevant texts. Still more important, we must understand the crucial distinction between the Old and the New Testaments, why this distinction is there, and what it means and does not mean. If this is ignored, we run once more into the sterile debate between people who say, 'The Bible says ...' and those who answer, 'Yes, and the Bible also says you should stone adulterers, and that you shouldn't wear clothes made of two types of cloth.' We urgently need to get past this unnecessary roadblock and on to more serious engagement. (p. 88)

The 'more serious engagement' Wright calls for, is summarised by his 'five-act hermeneutic'. Wright (2005) declares:

The Bible itself offers a model for its own reading, which involves knowing where we are within the overall drama and what is appropriate within each act. The acts are: creation, 'fall', Israel, Jesus, and the church; they constitute the differentiated stages in the divine drama which scripture itself offer. (p. 89)

Wright (2005:88) points out that 'it is vital that we understand scripture, and our relation to it, in terms of some kind of overarching narrative which makes sense of the texts'.

Wright (2005) locates present-day Christians in the 'fifth act':

Those who live in this fifth act have an ambiguous relationship with the four previous acts, not because they are being disloyal to them but precisely because they are being loyal to them as part of the story. If someone in the fifth act of All's Well that Ends Well were to start repeating speeches from earlier acts, instead of those which belonged to the fifth act itself, the whole play would begin to unravel. We must act in the appropriate manner for this moment in the story; this will be in direct continuity with the previous acts (we are not free to jump suddenly to another narrative, a different play altogether), but such continuity also implies discontinuity, a moment where genuinely new things can and do happen. We must be ferociously loyal to what has gone before and cheerfully open about what must come next. (p. 89)

This, then, is how Wright proposes we bridge the gap from the ancient to the modern worlds: by imagining ourselves as players in a later stage of the same grand drama of Scripture (cf. Bartholomew \& Goheen 2014). Christian ethics becomes living in a way consistent with the thrust of the story, while recognising that absolute adherence to the injunctions of earlier parts entails unfaithfulness, since it fails to reckon adequately with the original meaning and how the story has itself progressed. Wright (2005) calls on Christians to 'improvise' in a way consistent with the preceding story:

The New Testament offers us glimpses of where the story is to end: not with us 'going to heaven', as in many hymns and prayers, but with new creation. Our task is to discover, through the Spirit and prayer, the appropriate ways of improvising the script between the foundation events and charter on the one hand and the complete coming of the kingdom on the other. Once we grasp this framework, other things begin to fall into place. (p. 92)

Wright's vision is one way of articulating an eschatological hermeneutic - a way of reading the Bible that locates God's people in the movement towards the new creation. Such a hermeneutic has the advantage of taking Scripture's present role in society seriously, while avoiding the proof-texting endemic in fundamentalism. In fact, what differentiates it from fundamentalism, is the recognition of the Bible's grand narrative and the need to consider texts' contribution to modern discussions, based on the way in which they fit into that grand narrative.

It may be argued that Wright does the very thing we are critiquing fundamentalism of doing, by importing his own debatable - theological understanding of Scripture. While this is certainly the case, the point is that the hermeneutic is at least acknowledged, and is defensible if one accepts a canonical understanding of Scripture.

Another advantage is that this hermeneutic provides the grounds for a robust theory of present-day social involvement. If we are living in the 'fifth act', we are to live out the future in the present. Therefore, our vison of a renewed, good, just world shapes our ethic in the present. How this shapes ecclesiology, has been well put by Bird (2013):

The church also announces the victory of the Lord Jesus in the gospel and attempts to make this victory a present experience as much like the future as possible. For a start, the bride and the Spirit invite others to come to the wedding feast and to drink from the free gift of the water of life. We also disempower the powers, moral or political, that enslave people and dehumanize them, precisely because this is what the Lord intends to do to them on the last day. Injecting eschatology into our ecclesiology, far from paralyzing church action with the inertia of waiting, is instead a primary motivation for the message and ministry that the church carries out. (p. 729)

Christian ethics, rather than merely 'following Scripture', as a book like Biblical principles for Africa might put it, becomes a matter of faithful living in the last days: making the victory of Jesus 'a present experience as much like the future as possible' (Bird 2013:729). The eschatological hermeneutic is a method among others (cf. Hays 1995; McKnight 2018; Webb 2001) - of talking about Scripture and its application in a way that avoids using the Bible in a naïve manner, that merely quotes verses without declaring an overall scheme for their interpretation. South African theology - not least the 
conservative brand - needs to be able to articulate its hermeneutic, if we are to be able to avoid the misinterpretation of Scripture.

To be clear, the argument here is not that Wright's model must be embraced. Instead, I am arguing that fundamentalist hermeneutics has failed to define what 'biblical' looks like in practice, and so tends to misinterpret Scripture. Wright's eschatological approach provides one method of attending to this failure, and it provides a way forward for a better interpretation of Scripture.

\section{Conclusion}

The intent of this article is to describe a basic problem in the interplay between Scripture and society: fundamentalist readings of Scripture appear to dominate the popular landscape. But the article also attempts to chart a course forward toward a chastened - more reader-centred - approach to the interpretation of Scripture. An interpretation that is focused on the eschatological trajectory of the biblical story. The approach could be termed: a 'redemptive-historical' hermeneutic. This was offered as merely one approach to interpreting and applying Scripture in a way that is faithful to its overall thrust and relevant to modern times.

We are grateful that the Bible Society has been publishing in South Africa for 200 years. This article intends to highlight the importance of the interpretation of Scripture alongside its publication.

\section{Acknowledgements}

A contribution for the conference: 'The impact of the Bible on our society: Past, present and future' (2021) in celebration of the 200th anniversary of the Bible Society in South Africa.

\section{Competing interests}

The author declares that he has no financial or personal relationships that may have inappropriately influenced her in writing this article.

\section{Author's contributions}

I declare that I am the sole author of this research article.

\section{Ethical considerations}

This article followed all ethical standards for a research without direct contact with human or animal subjects.

\section{Funding information}

The author received no financial support for the research, authorship, or publication of this article.

\section{Data availability}

Data sharing is not applicable to this article as no new data were created or analysed in this study.

\section{Disclaimer}

The views and opinions expressed in this article are those of the author and do not necessarily reflect the official policy or position of any affiliated agency of the author.

\section{References}

African Christian Democratic Party (ACDP), 2019, African Christian Democratic Party 2019 Manifesto national elections, viewed n.d., from https://www.acdp.org.za/ wp-content/uploads/2020/02/2019_Manifesto_National.pdf

African Christian Democratic Party (ACDP), 2020, ACDP policies, viewed n.d., from https://www.acdp.org.za/policies/

Balcomb, A.O., 2016, 'Evangelicalism in Africa: What it is and what it does', Missionalia 44(2), 117-128. https://doi.org/10.7832/44-2-142

Barr, J., 1981, Fundamentalism Rev. edn, SCM Press, London.

Bartholomew, C.G., 2000, 'Uncharted waters: Philosophy, theology and the crisis in biblical interpretation', in C.G. Bartholomew, C. Greene \& K. Moller (eds.) Renewing biblical interpretation, pp. 1-39, Paternoster Press, Carlisle.

Bartholomew, C.G. \& Goheen, M.W., 2014, Drama of scripture, Baker Academic, Grand Rapids, MI.

Bird, M.F., 2013, Evangelical theology, Zondervan Academic, Grand Rapids, MI.

Deist F.E., 1994, 'The dangers of Deuteronomy: A page from the reception history of the book', in F.G. Martinez, A. Hilhorst, J.T.A.G.M. van Ruiten \& A.S. van der Woude (eds.), Studies in Deuteronomy: In honour of C.J. Labuschagne on the occasion of his 65th birthday, pp. 13-29., Brill, Leiden.

Enns, P., 2015, Inspiration and incarnation, 2nd edn., Baker Academic, Grand Rapids, MI.

Forster, D., 2021, Trump is out, but US evangelicalism remains alive and well in Africa viewed n.d., from https://theconversation.com/trump-is-out-but-usevangelicalism-remains-alive-and-well-in-africa-151117

Gadamer, H., 1982, Truth and method, 2nd edn., transl. eds. G. Barden \& J. Cumming Crossroad, New York, NY.

Gushee, D.P., 2016, Kingdom ethics, Eerdmans, Grand Rapids, MI.

Hammond, P., 2008, Biblical principles for Africa, Christian Liberty Books, Cape Town. Hays, R.B., 1995, Moral vision of the New Testament, Harper One, New York, NY. Jacobs, A.J., 2007, The year of living biblically, Simon \& Schuster, New York, NY.

Kairos Document: Challenge to the church, 1986, rev. 2nd edn., The ICT on behalf of the Kairos theologians, viewed 05 April 2021, from http://ujamaa.ukzn.ac.za/ Libraries/manuals/The_Kairos_Documents.sflb.ashx

Kearney, R., 2004, Debates in continental philosophy, Fordham University Press, New York, NY.

McKnight, S., 2018, Blue Parakeet, 2nd edn., Zondervan, Grand Rapids, MI.

News24, 2020, Mogoeng prays against any Covid-19 vaccine 'from the devil' to be 'destroyed by fire', viewed n.d., from https://www.news24.com/news24/ southafrica/news/mogoeng-prays-against-any-covid-19-vaccine-from-the-devilto-be-destroyed-by-fire-20201210

Osborne, G.R., 2006, Hermeneutical spiral, rev. \& exp. edn., IVP Academic, Downers Grove, IL.

Pickering, J., 2019, Turn neither right not left, Wipf \& Stock, Eugene, OR

Smith, C., 2012, Bible made impossible, Brazos Press, Grand Rapids, MI.

Thiselton, A.C., 1997, New horizons in hermeneutics, Zondervan Academic, Grand Rapids, MI.

Vanhoozer, K.J., 1998. Is there a meaning in this text?, Zondervan, Grand Rapids, MI. Webb, W.J., 2001, Slaves, women, homosexuals, InterVarsity Press, Downers Grove, IL. West, G., 1991, Biblical hermeneutics of liberation, Cluster Publications, Pietermaritzburg. (Cluster Monograph series 1).

Westphal, M., 2012, 'The philosophical/theological view', in S.E. Porter \& B.M. Stovell (eds.), Biblical hermeneutics: Five views, pp. 70-88, IVP Academic, Downers Grove, IL.

Wright, N.T., 1992, The New Testament and the people of God, Fortress Press, Minneapolis, MN.

Wright, N.T., 2005, Scripture and the Authority of God., HarperCollins, London. 